\title{
A SEASONAL ECOLOGICAL STUDY OF FORAMINIFERA FROM TIMBALIER BAY, LOUISIANA
}

\author{
ROBERT P. WALDRON ${ }^{1}$
}

\begin{abstract}
Within the last decade, considerable attention has been directed toward understanding the ecological habits of Foraminifera. This study has ventured deeper than previous ones in an attempt to learn the habits of living Foraminifera from Timbalier Bay, Louisiana, over a period of a year.

Ten monthly collections of samples were made from seventeen locations in the bay. Data relating to salinity, temperature, $\mathrm{pH}$, eh and other chemical and physical properties of the waters were recorded at this time.

Upon examination -of the samples, it was determined that twenty-three species of Foraminifera could be considered common in the bay. Two facies zones were recognized within this polyhaline bay by the restriction of certain species to characteristic areas.

Reproduction of the Foraminifera appeared to be dependent upon the environmental factors of salinity and temperature. The use of water chemistry, other than salinity, to explain the reproductive habits of the Foraminifera proved unsuccessful.

Availability of nutrients is believed to be the principal cause of differences in total populations of living Foraminifera within the bay. These nutrients are probably derived from the land areas and transported around the bay by the normal water flow. Three periods of inflow of these materials into the bay were noted.

There has been no comparable foraminiferal study of this bay. A recent foraminiferal study of several bays in Texas (Phleger and Lankford, 1957) is quite similar, but the periods between collections were longer, and no attempts were made to correlate the Foraminifera with the chemical properties of the bay. Myers (1943) studied the effects of food, substratum, depth, temperature, $\mathrm{pH}$, oxygen tension, turbulence, turbidity, animal associations, parasites and enemies on a single species, Elphidium crispum, over a period of a year.
\end{abstract}

${ }^{1}$ Consulting Geologist, Kenner, Louisiana. 